\title{
KAJIAN HUKUM TERHADAP PELAKU TABRAK LARI YANG MENGAKIBATKAN KEMATIAN BERDASARKAN PASAL 310 \\ AYAT (4) DAN 312 UNDANG-UNDANG NOMOR 22 TAHUN 2009 TENTANG LALU LINTAS DAN ANGKUTAN JALAN JO PASAL 359 KUHP
}

\author{
Riky Pribadi,S.H.,M.H \& Diki Maryana
}

rikypribadi87@unma.ac.id

\begin{abstract}
ABSTRAK
Kecelakaan lalu lintas yang pelakunya tidak bertanggung jawab, dengan membiarkan korbannya begitu saja tanpa menghentikan kendaraannya sering di sebut dengan tabrak lari. Namun ada beberapa faktor yang kerap dijadikan alasan bagi pelaku tabrak lari, yakni, pelaku takut dihajar masa, enggan berurusan dengan hukum yang terlalu berbelit-belit, dan terjadi di tempat yang sepi, sehingga besar kemungkinan untuk melarikan diri.

Penelitian ini menggunakan pendekatan yuridis normatif dan sifat penelitian ini adalah deskriptif analitis. Pengambilan data dilakukan melalui studi kepustakaan dalam rangka memperoleh data sekunder, baik yang berupa bahan hukum primer, bahan hukum sekunder, maupun bahan hukum tertier. Untuk mendukung penelitian yang telah dilakukan, dilaksanakan pula penelitian lapangan dalam rangka memperoleh data primer yang menunjang data sekunder. Adapun teknis analisis yang dipergunakan dalam penelitian ini adalah teknik analisis kualitatif.

Berdasarkan hasil penelitian diketahui bahwa hukum positif yang mengatur mengenai tindak pidana tabrak lari dalam Undang-Undang Nomor 22 Tahun 2009 diatur secara terpisah, yakni kelalaian yang menyebabkan kecelakaan diatur dalam Pasal 310 ayat (4) dan tindakan melarikan diri dalam Pasal 312. Dengan demikian dapat dikatakan bahwa tabrak lari merupakan perbarengan tindak pidana (Concursus). Oleh sebab itu jika dikaitkan dengan teori negara hukum Pancasila maka, negara tidak dikehendaki hanya membatasi fungsinya untuk pembuatan peraturan-peraturan pidana saja, melainkan lebih jauh lagi yaitu bagaimana melindungi dan menangani permasalahan tabrak lari yang menimbulkan korban meninggal dunia. Jika kita kaitkan dengan teori pertanggungjawaban pidana, unsur-unsur kesalahan pelaku tabrak lari harus dihubungkan dengan tindak pidana yang dilakukan.
\end{abstract}

Kata Kunci: Tabrak Lari, Kematian, Undang-Undang 
PRESUMPTION of LAW

Fakultas Hukum Universitas Majalengka

Volume 2 Nomor 2 Oktober 2020

\section{A. Latar Belakang Masalah}

Kecelakaan yang sering terjadi dijalan banyak diartikan sebagai suatu penderitaan yang menimpa diri seseorang secara mendadak dan keras yang datang dari luar. Begitu pula dijelaskan dalam Undang-Undang Nomor 22 Tahun 2009 Tentang Lalu Lintas Dan Angkutan Jalan, mengungkapkan kecelakaan lalu lintas adalah suatu peristiwa di jalan yang tidak diduga dan tidak disengaja yang melibatkan kendaraan dengan atau tanpa pengguna jalan lain yang mengakibatkan korban manusia dan/atau kerugian harta benda ${ }^{1}$.

Kecelakaan lalu lintas yang pelakunya tidak bertanggung jawab, dengan membiarkan korbannya begitu saja tanpa menghentikan kendaraannya, atau di sebut dengan tabrak lari. ${ }^{2}$ Tabrak lari adalah tindak pidana kejahatan yang tidak manusiawi, terlebih korban meninggal dunia akibat perbuatan pelaku tersebut. Tabrak lari juga merupakan tindakan yang mengabaikan nilai-nilai kemanusiaan sebagai makhluk yang bermoral. Salah satu dari nilai moral adalah mengenai pribadi manusia yang bertanggungjawab

Secara spesifik dalam Undang-Undang Nomor 22 Tahun 2009 Tentang Lalu Lintas Dan Angkutan Jalan, tidak menyebutkan definisi tabrak lari, hanya saja setiap terjadi kecelakaan, ketika pelaku melarikan diri, tidak menghentikan kendaraannya, tidak menolong, dan tidak melapor ke kepolisian terdekat. Perbuatan tersebut dapat diasumsikan sebagai pelaku tabrak lari .

Tabrak lari pada mulanya peristiwa kecelakaan karena kelalaian, yang mana kelalaian dalam berkendara telah diatur dalam Pasal 310 UU No. 22 Tahun 2009 Tentang Lalu Lintas Dan Angkutan Jalan. Kemudian perbuatan kelalaian yang mengakibatkan korban tersebut bersamaan dengan perbuatan yang tidak bertanggung jawab, yakni meninggalkan korban atau melarikan diri. Pemicu terjadinya kecelakaan termasuk tabrak lari adalah runtuhnya etika dalam berkendara ${ }^{3}$. Berbagai kecaman dari berbagai pihak mengenai tabrak lari, menjadikan pihak yang berwajib (polisi) tidak tinggal diam. Mereka mengadakan penyelidikan dan penyidikan guna menemukan pelaku dan mengumpulkan bukti-bukti yang ada khususnya tabrak lari, merupakan kasus yang harus diungkap, sehingga dapat diketahui apakah perbuatan tersebut merupakan perbuatan yang tergolong sebagai tabrak lari saja atau terdapat motif lain, seperti pembunuhan berencana dengan menggunakan modus tabrak lari.

Ketika hasil penyelidikan dan penyidikan menunjukkan bahwa kecelakaan yang terjadi adalah perbuatan kesengajaan dan telah direncanakan. Maka hukumannya akan lebih berat, karena korban ditabrak dengan sengaja. Hal ini bukan tergolong sebagai tabrak lari, melainkan pembunuhan berencana yang menggunakan alat berupa kendaraan bermotor, yang mana dalam

${ }^{1}$ Lihat Pasal 1 angka 24 Undang-Undang Nomor 22 Tahun 2009 Tentang Lalu Lintas Dan Angkutan Jalan

${ }^{2}$ Marye Agung Kusmagi, Selamat Berkendara Dijalan raya, Raih Asa Sukses, Jakarta, 2010,hlm. 94

${ }^{3}$ Toto Suprapto, Keprihatinan Etika Berlalu Lintas, dalam Suara Merdeka, Semarang, 19 September 2011, hlm. 7 
PRESUMPTION of LAW

Fakultas Hukum Universitas Majalengka

Volume 2 Nomor 2 Oktober 2020

tindakan tersebut murni kesengajaan, namun berbeda halnya dengan tabrak lari yang mengandung unsur kelalaian dan kesengajaan. Kelalaian atau kealpaan sendiri merupakan sikap yang kurang hati-hati, ${ }^{4}$ dan kealpaan diantaranya diatur dalam Pasal 359 KUHP disebutkan bahwa: " Barang siapa karena kealpaannya menyebabkan matinya orang lain, diancam dengan pidana penjara paling lama lima tahun atau kurungan paling lama satu tahun". 5

Berbicara mengenai pelaku tabrak lari yang menyebabkan luka ringan, luka berat hingga meninggal dunia pada kecelakaan lalu lintas, semua tidak terlepas dari pertanggungjawaban pidana untuk mempertanggungjawabkan perbuatan pidana. Dalam sistem hukum yang dianut oleh Indonesia terdapat asas "Gen Straf Zonder Schuld" yaitu tiada pidana tanpa kesalahan sebagai dasar untuk meminta pertanggungjawaban seseorang atau sesuatu badan hukum. ${ }^{6}$ Pertanggungjawaban pidana, tidak dapat dilepaskan dengan tindak pidana. Walaupun di dalam pengertian tindak pidana tidak termasuk masalah pertanggungjawaban pidana. Tindak pidana hanya menunjuk kepada dilarangnya suatu perbuatan.

Tindak pidana tidak berdiri sendiri, itu baru bermakna manakala terdapat pertanggungjawaban pidana. Ini berarti setiap orang yang melakukan tindak pidana tidak dengan sendirinya harus dipidana. Untuk dapat dipidana harus ada pertanggungjawaban pidana. Pertanggungjawaban pidana lahir dengan diteruskannya celaan (verwijtbaarheid) yang objektif terhadap perbuatan yang dinyatakan sebagai tindak pidana berdasarkan hukum pidana yang berlaku, dan secara subjektif kepada pembuat yang memenuhi persyaratan untuk dapat dikenai pidana karena perbuatan tersebut. Begitu pula menurut Dwidja Priyatno yang menyatakan bahwa pertanggungjawaban pidana itu sendiri adalah diteruskannya celaan yang objektif yang ada pada tindak pidana dan secara subjektif kepada seseorang yang memenuhi syarat untuk dapat dijatuhi pidana karena perbuatannya itu ${ }^{7}$.

Masalah pertanggungjawaban pidana merupakan masalah yang sangat penting dalam upaya penegakan hukum dalam penanggulangan tindak pidana tabrak lari yang mengakibatkan hilangnya nyawa seseorang, namun tindak pidana ini sangat sulit dalam mengungkap pelakunya jika tidak ada saksi saat kecelakaan itu terjadi.

Berdasarkan uraian di atas, maka penulis tertarik untuk mengkaji mengenai pelaku tabrak lari yang mengakibatkan kematian kecelakaan lalu lintas . Oleh karena itu dalam penelitian hukum ini penulis mengambil judul penulisan : Kajian Hukum Terhadap Pelaku Tabrak Lari Yang Mengakibatkan Kematian Berdasarkan Pasal 310 Ayat (4) Dan 312 Undang-Undang Nomor 22 Tahun 2009 Tentang Lalu Lintas Dan Angkutan Jalan Jo Pasal 359 KUHP.

\footnotetext{
${ }^{4}$ Sudarto, Hukum Pidana I, Yayasan Sudarto, 1990, Semarang, hlm. 125

${ }^{5}$ Moeljatno, Kitab Undang-undang Hukum Pidana, Bumi Aksara., Jakarta, 2009,hlm. 127

${ }^{6}$ Erdianto, Pokok-Pokok Hukum Pidana, Alaf Riau, Pekanbaru, 2010, hlm. 62.

${ }^{7}$ Dwidja Priyatno, Kebijakan Legislasi Tentang Sistem Pertanggungjawaban Pidana Korporasi di Indonesia, CV.Utomo, Bandung, 2009,hlm.40.
} 
PRESUMPTION of LAW

Fakultas Hukum Universitas Majalengka

Volume 2 Nomor 2 Oktober 2020

\section{B. Identifikasi Masalah}

Sesuai dengan latar belakang yang diuraikan di atas, maka identifikasi masalah penelitian ini ditetapkan sebagai berikut:

1. Bagaimana kajian hukum positif terhadap pelaku tabrak lari yang mengakibatkan kematian?

2. Faktor apa sajakah yang menjadi kendala dalam penegakan hukum tabrak lari yang mengakibatkan kematian?

\section{Tujuan Penelitian}

Berdasarkan identifikasi masalah yang telah ditetapkan di atas, maka secara khusus penelitian ini bertujuan untuk:

1. Untuk mengetahui dan menganalisis kajian hukum positif terhadap pelaku tabrak lari yang mengakibatkan kematian

3. Untuk mengetahui faktor yang menjadi kendala dalam penegakan hukum tabrak lari yang mengakibatkan kematian?

\section{Kegunaan Penelitian}

Kegunaan atau manfaat penelitian yang hendak dicapai secara umum dalam suatu penelitian dapat dibedakan dalam 2 (dua) aspek, yaitu aspek teoritis (akademis) dan aspek praktis (gunalaksana). Sehubungan dengan penelitian ini, maka kegunaan yang diharapkan dari penelitian yang disusun dalam bentuk proposal ini, adalah:

1. Secara Teoritis penelitian diharapkan dapat memberikan sumbangan pemikiran dalam rangka pengembangan pengetahuan ilmiah bidang hukum pidana, terutama masalah tabrak lari.

2. Aspek praktis (guna laksana), diharapkan dapat memberikan tambahan informasi baru atau dapat memberikan masukan konstrukstif (sumbangan pemikiran bagi pemerintah dan lembaga legislatif dalam upaya penyempurnaan peraturan perundang-undangan yang terkait aspek-aspek hukum pidana, khususnya dalam bidang hukum lalu lintas dan angkutan jalan.

\section{E. Kerangka Pemikiran}

Fungsi kerangka pemikiran (berpikir) dalam suatu penelitian adalah sebagai tempat yang berisikan pertimbangan-pertimbangan ilmiah terhadap penelitian yang dilaksanakan. Kerangka pemikiran dalam penelitian merupakan tulang punggung penelitian, karena di sini diuraikan landasan-landasan ilmiah atau teori yang digunakan untuk menganalisis temuan penelitian. ${ }^{8}$

Sehubungan dengan permasalahan yang telah diuraikan di atas, maka kerangka pemikiran penelitian ini menggunakan teori Negara Hukum yang

${ }^{8}$ Sugiyono, Metode Penelitian Kuantitatif, Kualitatif dan $R \& D$, Cetakan Kesembilan, Alfabeta,Bandung, 2010, hlm. 60. Lihat juga Uma Sekaran, Research Methods for Business, A Skill-Building Approach, Illionis: Southern Illionis University at Carbondale (SIUC), 1984, p. 80. 
PRESUMPTION of LAW

Fakultas Hukum Universitas Majalengka

Volume 2 Nomor 2 Oktober 2020

berdasarkan Pancasila, teori hukum pembangunan serta didukung dengan teori kepastian hukum dan teori pertanggungjawaban pidana

Hakikat negara hukum didasarkan pada konsep teori Kedaulatan Negara (Soeverignty) yang pada prinsipnya menyatakan kekuasaan tertinggi di dalam suatu negara adalah hukum. Seluruh alat perlengkapan negara apa pun namanya, termasuk warga negara harus tunduk dan patuh serta menjunjung tinggi hukum tanpa kecuali. ${ }^{9}$ Ateng sudibyo mengutip pendapat Krisna Harahap mengatakan bahwa: Konsep pemikiran negara hukum seperti ini sebenarnya dapat dilihat dari awal munculnya teori Negara Hukum yang dimulai sejak abad XIX hingga abad XX. ${ }^{10}$

Muhammad Tahir Azhary mengutip pendapat Oemar Seno Adji mengatakan bahwa: Negara Hukum Indonesia mempunyai ciri khas Indonesia, karena mempunyai pandangan hidup bernegara yaitu Pancasila. Pancasila harus diangkat sebagai dasar pokok dan sumber hukum, maka Negara Hukum Indonesia dapat pula disebut Negara Hukum Pancasila. Salah satu ciri pokok dalam Negara Hukum Pancasila adalah adanya jaminan terhadap kebebasan beragama (freedom of religion). ${ }^{11}$ Muhammad Tahir Azhary selanjutnya mengatakan bahwa walaupun dalam Penjelasan UUD 1945 digunakan istilah rechtstaats, tetapi yang dianut oleh Negara Indonesia bukan konsep rechtstaats dan bukan pula konsep the rule of law, melainkan konsep Negara Hukum Pancasila yang mempunyai ciri-ciri: (1) ada hubungan yang erat antara agama dan negara; (2) bertumpu pada Ketuhanan Yang Maha Esa; (3) kebebasan beragama dalam arti positif; (4) ateisme tidak dibenarkan dan komunisme dilarang; (5) asas kekeluargaan dan kerukunan. ${ }^{12}$ Dalam pendapat lain menurut Menurut Philipus M. Hadjon, ${ }^{13}$ dijelaskan bahwa ciri negara hukum Pancasila, yaitu: (1) keserasian hubungan antara pemerintah dan rakyat berdasarkan asas kerukunan; (2) hubungan fungsional yang proposional antara kekuasaankekuasaan negara; (3) prinsip penyelesaian sengketa secara musyawarah dan peradilan merupakan sarana terakhir; dan (4) keseimbangan antara hak dan kewajiban.

Menurut Mochtar Kusumaatmadja, Hukum berfungsi sebagai sarana pembaharuan adalah didasarkan atas anggapan bahwa hukum dalam arti kaidah atau peraturan hukum memang bisa berfungsi sebagai alat (pengatur) atau sarana pembaharuan dalam arti penyalur arah kegiatan orang ke arah yang

${ }^{9}$ B. Hestu Cipto Handoyo, Hukum Tata Negara, Kewarganegaraan \& Hak Asasi Manusia, Memahami Proses Konsolidasi Sistem Demokrasi di Indonesia, Cetakan Pertama, Universitas Atma Jaya, Yogyakarta, 2003, hlm. 12.

10 Ateng Sudibyo, Kebijakan Kriminal Tindak Pidana Poligami Dalam Hukum Perkawinan Di Indonesia, CV. Andy Oetama, Medan, 2018, hlm 125

${ }^{11}$ Muhammad Tahir Azhary, Negara Hukum: Suatu Studi tentang Prinsip-prinsipnya Dilihat dari Segi Hukum Islam, Implementasinya pada Periode Negara Madinah dan Masa Kini, Bulan Bintang, Jakarta, 1992, hlm. 69.

${ }^{12}$ Ibid, hlm. 71.

${ }^{13}$ Philipus M. Hadjon, Perlindungan Hukum bagi Rakyat Indonesia, Bina Ilmu, Surabaya, 1987, hlm. 90. 
PRESUMPTION of LAW

Fakultas Hukum Universitas Majalengka

Volume 2 Nomor 2 Oktober 2020

dikehendaki oleh pembangunan ${ }^{14}$. Konsep hukum sebagai sarana pembaharuan masyarakat sebelumnya telah dirumuskan oleh Roscoe Pound pada tahun 1912 dalam bukunya; "Scope and Purposive of Sociological Jurisprudence". Pound mengatakan, hukum dapat berfungsi sebagai alat merekayasa masyarakat (law as a tool of social engineering) dan tidak hanya sekedar melestarikan status quo. ${ }^{15}$

Michael Heger ${ }^{16}$, menjabarkan hubungan antara hukum dan pembangunan dengan mengintrodusir konsep development law atau hukum pembangunan yang meliputi: "Suatu sistem yang sensitif terhadap pembangunan yang meliputi keseluruhan hukum substantif, lembaga-lembaga hukum berikut ketrampilan para sarjana hukum secara aktif mendukung pembangunan. Konsep Development law meliputi tindakan dan kegiatan yang memperkuat infra struktur hukum seperti lembaga-lembaga hukum, profesiprofesi hukum, lembaga-lembaga pendidikan hukum dan lainnya, serta segala sesuatu yang berkenan dengan penyelesaian problema-problema khusus pembangunan dan pembaharuan dalam masyarakat."

Menurut Michael Heger, hukum dalam fungsinya sebagai sarana pembangunan dapat mengabdi pada tiga sektor yaitu :

1. Hukum sebagai alat penertiban (ordering).

2. Hukum sebagai alat penjaga keseimbangan (balancing).

3. Hukum sebagai katalistor.

Secara teoritika, dapat ditemukan bahwa teori hukum pembangunan dari Mochtar Kusumaatmadja dapat dijadikan dasar dalam melakukan kebijakan hukum yang menunjang pembangunan hukum, khususnya pengaturan tindak pidana ujuran kebencian, sebagaimana diatur dalam Undang-Undang Nomor 22 Tahun 2009 tentang Lalu Lintas Dan Angkutan Jalan, dalam menentukan pencegahan tindak pidana tabrak lari, yaitu bahwa dengan cara menemukan gagasan baru, regulasi dan revitalisasi terhadap peraturan yang sudah ada, yang bersumber pada nilai-nilai yang hidup dalam masyarakat.

Terhadap istilah kepastian hukum, ada beberapa pengertian yang dapat dikemukakan. Menurut Sudikno Mertokusumo, ${ }^{17}$ kepastian hukum merupakan perlindungan yustisiabel terhadap tindakan sewenang-wenang yang berarti bahwa seseorang akan dapat memperoleh sesuatu yang diharapkan dalam keadaan tertentu. Masyarakat mengharapkan adanya kepastian hukum, dimana dengan kepastian hukum masyarakat akan lebih tertib. Sebaliknya, masyarakat juga mengharapkan manfaat dalam pelaksanaan atau penegakan hukum adalah

${ }^{14}$ Mochtar Kusumaatmadja, Hukum, masyarakat dan pembinaan hukum Nasional, Binacipta, Jakarta, 1995, hlm. 12-13.

${ }^{15}$ Roscoe Pound, An Introduction to the Philosophy of Law, Yale University Press, United States, 1922, hlm. 47.

${ }^{16}$ Hager, Michael., Development for the Developing Nations, Work paper in World Peace Thought Law, 1973, dalam Syamsuharya Berhan. Penerapan Prinsip Hukum Pelestarian Fungsi Lingkungan Hidup dalam Aktivitas Industri nasional. Sebuah Upaya Penyelamatan Lingkungan Hidup dan Kehidupan Antar Generasi, P.T Alumni,Bandung: 2008, hlm.25.

17 Sudikno Mertokusumo, Bab-bab tentang Penemuan Hukum, Citra Aditya Bakti, Bandung, 1993, hlm. 1-2. 
PRESUMPTION of LAW

Fakultas Hukum Universitas Majalengka

Volume 2 Nomor 2 Oktober 2020

diciptakan untuk mengatur manusia, maka pelaksanaan hukum atau penegakan hukum tentang tablak lari, harus memberi manfaat atau kegunaan bagi masyarakat. Jangan sampai justru karena hukumnya dilaksanakan atau ditegakkan timbul keresahan di dalam masyarakat.

Secara normatif kepastian hukum dapat terwujud jika peraturan dibuat dan diundangkan secara pasti karena mengatur secara jelas dan logis. Jelas dalam pengertian tidak menimbulkan keragu-raguan (multitafsir) dan logis dalam pengertian menjadi suatu sistem norma dengan norma lain sehingga tidak berbenturan atau menimbulkan konflik norma. Konflik norma yang ditimbulkan dari ketidakpastian aturan dapat berbentuk kontestasi norma, reduksi norma atau distorsi norma. ${ }^{18}$

Perlindungan hukum terhadap korban tabrak lari merupakan suatu perbuatan dalam melindungi subjek-subjek hukum dengan peraturan perundang-undangan yang berlaku dan pelaksanaannya dapat dipaksakan dengan suatu sanksi. Disamping itu jika seseorang melakukan kesalahan, menurut Prodjohamidjojo, dipandang sebagai suatu tindak pidana, yang dilihat dari segi masyarakat patut di cela. Dengan demikan, menurutnya seseorang mendapatkan pidana tergantung pada dua hal, yaitu (1) harus ada perbuatan yang bertentangan dengan hukum, atau dengan kata lain, harus ada unsur melawan hukum. Jadi harus ada unsur Obejektif, dan (2) terhadap pelakunya ada unsur kesalahan dalam bentuk kesengajaan dan atau kealpaan, sehingga perbuatan yang melawan hukum tersebut dapat di pertanggungjawabkan kepadanya jadi ada unsur subjektif ${ }^{19}$.

Menurut Romli Atmasasmita, pertanggungjawaban pidana (criminal liability) diartikan sebagai suatu kewajiban hukum pidana untuk memberikan pembalasan yang akan diterima pelaku terkait karena orang lain yang dirugikan. Sehubungan dengan hal tersebut, Romli Atmasasmita menyatakan sebagai berikut:

"Berbicara tentang konsep liability atau "pertanggungjawaban" dilihat dari segi falsafat hukum, seorang filosof besar dalam bidang hukum pada abad ke-20, Roscou Pound, dalam An Introduction to the Philosophy of Law, telah mengemukakan pendapatnya "I .... Use the simple word "liability" for the situation whereby one exact legally and other is legally subjected to the exaction". 20

Bertitik tolak pada rumusan tentang "pertanggungjawaban" atau liability tersebut di atas, Pound membahasnya dari sudut pandang filosofis dan sistem hukum secara timbal balik. Secara sistematis, Pound lebih jauh menguraikan perkembangan konsepsi liability. Teori pertama, menurut Pound, bahwa

\footnotetext{
${ }^{18}$ Yance Arizona, “Apa Itu Kepastian Hukum?”, http://yancearizona.wordpress. com, diakses tanggal 12 November 2019.

${ }^{19}$ Martiman Prodjohamidjojo, Memahami dasar-dasar hukum Pidana Indoesia,PT. Pradnya Paramita, Jakarta 1997, hlm 31

${ }^{20}$ Romli Atmasasmita, “Asas-asas Perbandingan Hukum Pidana”, Yayasan LBH, Jakarta, 1989, hlm.79. Lihat juga Romli Atmasasmita, Perbandingan Hukum Pidana Kontomporer, Fikahati Aneska, Jakarta, 2009,hlm.84.
} 
PRESUMPTION of LAW

Fakultas Hukum Universitas Majalengka

Volume 2 Nomor 2 Oktober 2020

liability diartikan sebagai suatu kewajiban untuk membayar pembalasan yang akan diterima pelaku dari seseorang yang telah "dirugikan". Sejalan dengan semakin efektifnya perlindungan undang-undang terhadap kepentingan masyarakat akan suatu kedamaian dan ketertiban, dan adanya keyakinan bahwa "pembalasan" sebagai suatu alat penangkal, maka pembayaran "ganti rugi" bergeser kedudukannya, semula sebagai suatu "hak istimewa" kemudian menjadi suatu "kewajiban". Ukuran "ganti rugi" tersebut tidak lagi dari nilai suatu pembalasan yang harus "dibeli", melainkan dari sudut kerugian atau penderitaan yang ditimbulkan oleh perbuatan pelaku yang bersangkutan. ${ }^{21}$

Begitu pula dalam membicarakan tentang pertanggungjawaban pidana berdasarkan hukum pidana negara-negara yang menganut 'common law system', pada prinsipnya tidak memiliki perbedaan yang fundamental dengan 'civil law system'. Hukum pidana Inggris mensyaratkan bahwa "pada prinsipnya setiap orang yang melakukan kejahatan dapat dipertanggungjawabkan atas perbuatannya, kecuali ada sebab-sebab yang meniadakan penghapusan pertanggungjawaban yang bersangkutan (exemptions from liability),"22.

Kemampuan bertanggungjawab bila dilihat dari keadaan batin orang yang melakukan perbuatan pidana merupakan masalah kemampuan bertanggungjawab dan menjadi dasar yang penting untuk menentukan adanya kesalahan, yang mana keadaan jiwa orang yang melakukan perbuatan pidana haruslah sedemikian rupa sehingga dapat dikatakan normal, sebab karena orang yang normal, atau sehat inilah yang dapat mengatur tingkah lakunya sesuai dengan ukuran-ukuran yang dianggap baik oleh masyarakat. ${ }^{23}$

Selanjutnya, Sudarto menyatakan bahwa, disini berlaku asas "tiada pidana tanpa kesalahan" (Keine strafe ohne schuld atau geen straf zonder schuld atau nulla poene sine culpa). "Schuld" disini dalam arti luas, meliputi juga kesengajaan. Kesalahan (schuld) yang dimaksud adalah keadaan jiwa seseorang yang melakukan perbuatan dan perbuatan yang dilakukan itu sedemikian rupa, sehingga orang itu patut dicela ${ }^{24}$. Roeslan Saleh menyatakan, seseorang mempunyai kesalahan, apabila pada waktu melakukan perbuatan pidana dilihat dari segi kemasyarakatan, dia dapat dicela oleh karenanya, sebab dianggap dapat berbuat lain, jika memang tidak ingin berbuat demikian ${ }^{25}$.

Pertanggungjawaban pidana terhadap pelaku tabrak lari menjurus kepada pemidanaan pelaku, jika melakukan suatu tindak pidana dan memenuhi unsurunsur yang telah ditentukan oleh undang-undang. Dilihat dari terjadinya perbuatan yang terlarang, ia akan diminta pertanggungjawaban apabila perbuatan tersebut melanggar hukum. Dilihat dari sudut kemampuan

${ }^{21}$ Ibid, hlm 80 .

${ }^{22}$ Romli Atmasasmita, Perbandingan Hukum Pidana ... Op.Cit, hlm. 92-93.

${ }^{23}$ Sutrisna, I Gusti Bagus, "Peranan Keterangan Ahli dalam Perkara Pidana ( Tijauan terhadap pasal 44 KUHP)," dalam Andi Hamzah (ed.), Bunga Rampai Hukum Pidana dan Acara Pidana, Ghalia Indonesia, Jakarta,1986, hlm. 78

${ }^{24} \mathrm{Ibid}, \mathrm{hlm} 86$

${ }^{25}$ Roeslan Saleh, Perbuatan Pidana dan Pertanggungjawaban Pidana; Dua Pengertian Dasar dalam Hukum Pidana, Aksara Baru, Jakarta, 1983,hlm 77 
PRESUMPTION of LAW

Fakultas Hukum Universitas Majalengka

Volume 2 Nomor 2 Oktober 2020

bertanggungjawab maka hanya orang yang mampu bertanggungjawab yang dapat dimintai pertanggungjawaban.

\section{F. Metode Penelitian}

1. Spesifikasi Penelitian

Spesifikasi penelitian yang digunakan dalam penelitian ini adalah deskriptif analisis yaitu penelitian yang menggambarkan peraturan perundang- undangan yang berlaku dikaitkan dengan teori-teori hukum positif yang menyangkut permasalahan yang sedang diteliti. ${ }^{26}$

2. Metode Pendekatan

Metode Pendekatan yang digunakan dalam penelitian ini adalah pendekatan yuridis normatif, yaitu dengan mengkaji atau menganalisis data sekunder yang berupa bahan-bahan hukum sekunder dengan memahami hukum sebagai perangkat peraturan atau norma-norma positif di dalam sistem perundang-undangan yang mengatur mengenai permasalahan dalam penelitian ini. Jadi penelitian ini dipahami sebagai penelitian kepustakaan, yaitu penelitian terhadap data sekunder. ${ }^{27}$

3. Tahapan Penelitian

Tahap-tahap penelitian yang dilakukanadalah :

a. Studi Kepustakaan, yaitu mempelajari literatur-literatur untuk memperoleh data sekunder, yang terdiri dari bahan hukum primer, bahan hukum sekunder dan bahan hokum tertier. Bahan hukum primer adalah bahan hukum yang bersifat autoritatif (mempunyai otoritas), dan bahanbahan hukum yang mengikat, yakni norma (dasar) atau kaidah dasar dan peraturan-peraturan dasar, seperti Undang-Undang Dasar 1945, serta peraturan perundang-undangan yang berkaitan dengan tindak pidana tabrak lari, seperti Lalu Lintas Dan Angkutan Jalan dan Kitab UndangUndang Hukum Pidana. Bahan hukum sekunder adalah bahan hukum yang memberikan penjelasan mengenai bahan hukum primer, berupa hasil-hasil penelitian, karangan ilmiah dari kalangan hukum, dan penelitian-penelitian lain yang relevan dengan penelitian ini. Kemudian bahan hukum tertier adalah bahan yang memberikan petunjuk ataupun penjelasan terhadap bahan hukum primer dan bahan hukum sekunder, berupa kamus, ensiklopedia, majalah, surat kabar dan sebagainya yang dipergunakan untuk melengkapi ataupun menunjang data penelitian ini.

b. Studi Lapangan, yaitu dilakukan dalam rangka memperoleh data primer yang menunjang data sekunder, sehingga dari data primer akan dapat diketahui bagaimana pelaksanaan tindak pidana tabrak lari ditinjau dari Undang-Undang Nomor 22 Tahun 2009 Tentang Lalu Lintas Dan Angkutan Jalan.

4. TeknikPengumpulan Data

Teknik yang dipergunakan untuk mengumpulkan data primer dan data sekunder adalah :

${ }^{26}$ Soemitro Ronny Hanitijo, Metode Penelitian Hukum dan Yurimetri, Ghalia Indonesia, Jakarta, 1988, hlm. 11.

${ }^{27}$ Soerjono Soekanto dan Sri Mamudji, Penelitian Hukum Normatif, Suatu Tinjauan Singkat, Rajawali, Jakarta, 1985, hlm. 15. 
PRESUMPTION of LAW

Fakultas Hukum Universitas Majalengka

Volume 2 Nomor 2 Oktober 2020

a. Studi kepustakaan yaitu dengan mempelajari literatur-literatur yang berhu-bungan dengan objek penelitian.

b. Wawancara (interview) yaitu mengumpulkan data dengan cara tanya jawab dengan para pihak yang terkait dengan objek penelitian. Sedangkan tipe wawancara yang dipergunakan adalah wawancara tidak terpimpin (non directive interview) artinya seluruh wawancara tidak didasarkan pada satu sistem atau daftar pertanyaan yang telah disusun terlebih dahulu

c. Pengamatan (observasi) yaitu dengan cara mengamati secara langsung pada objek penelitian dengan mempergunakan pengamatan tidak terlibat (non-participation observation)

5. Analisis Data

Setelah data sekunder dan primer terkumpul, kemudian diadakan analisis secara kualitatif yaitu menganalisis data berupa uraian-uraian yang sistematis tanpa mempergunakan bagan-bagan dan rumus statistik.

6. Lokasi Penelitian

Lazimnya lokasi penelitian dilaksanakan di perpustakaan, di masyarakat dan lembaga atau instansi (pemerintah ataupun non-pemerintah). Sehubungan jenis data dalam penelitian yuridis normatif hanya berupa data sekunder, maka lokasi penelitian yang dipilih adalah perpustakaan pada Fakultas Hukum Universitas Majalengka, Kapolres Majalengka dan Pengadilan Negeri Majalengka.

\section{G. Hasil Penelitian Dan Pembahasan}

\section{A. Negara Hukum Dalam Menanggulangi Tindak Pidana Tabrak Lari}

setiap aturan hukum positif yang berlaku di Indonesia, haruslah mencerminkan nilai-nilai luhur dan murni yang terkandung dalam masingmasing sila Pancasila dan tentunya dituntun oleh sila Ketuhanan. Pencerminan nilai-nilai luhur dan murni Pancasila dalam setiap instrumen hukum yang berlaku di Indonesia, seharusnya merupakan unsur yang dapat membedakan konsep negara hukum Pancasila dengan konsep negara hukum (rechtsstaats atau the rule of law) yang umumnya dikenal pada negara lain. Hukum positif hendaknya diselaraskan dengan nilai-nilai yang terkandung dalam sila Pancasila dan oleh sebab itu, maka sistem hukum di Indonesia (termasuk dalam bidang hukum Pidana) haruslah mencerminkan nilai-nilai luhur dan murni yang terkandung pada masing-masing Sila Pancasila.

Teori Negara hukum dalam arti material atau konsep Negara Kesejahteraan berdasarkan Pancasila ini merupakan salah satu teori yang digunakan untuk menganalisis pengaturan tabrak lari, yaitu negara tidak dikehendaki hanya membatasi fungsinya untuk pembuatan peraturanperaturan pidana saja, melainkan lebih jauh lagi yaitu bagaimana melindungi dan menangani permasalahan tabrak lari yang menimbulkan korban meninggal dunia. 
PRESUMPTION of LAW

Fakultas Hukum Universitas Majalengka

Volume 2 Nomor 2 Oktober 2020

\section{B. Pertanggungjawaban Pidana dalam Tindak Pidana Tabrak Lari}

Berbicara tentang pertanggungjawaban pidana, maka tidak dapat dilepaskan dengan tindak pidana. Walaupun di dalam pengertian tindak pidana tidak termasuk masalah pertanggungjawaban pidana. Tindak pidana hanya menunjuk kepada dilarangnya suatu perbuatan.

Tindak pidana tidak berdiri sendiri, itu baru bermakna manakala terdapat pertanggungjawaban pidana. Ini berarti setiap orang yang melakukan tindak pidana tidak dengan sendirinya harus dipidana. Untuk dapat dipidana harus ada pertanggungjawaban pidana. Pertanggungjawaban pidana lahir dengan diteruskannya celaan (verwijtbaarheid) yang objektif terhadap perbuatan yang dinyatakan sebagai tindak pidana berdasarkan hukum pidana yang berlaku, dan secara subjektif kepada pembuat yang memenuhi persyaratan untuk dapat dikenai pidana karena perbuatan tersebut. Pertanggungjawaban pidana itu sendiri adalah diteruskannya celaan yang objektif yang ada pada tindak pidana dan secara subjektif kepada seseorang yang memenuhi syarat untuk dapat dijatuhi pidana karena perbuatannya itu ${ }^{28}$.

Bertitik tolak dari pendapat di atas, dalam Undang-Undang Lalu Lintas Dan Angkutan Jalan, perumusan pelaku tindak pidana menggunakan kata "setiap orang". Yang dimaksud dengan setiap orang dalam ketentuan Pasal 312 Undang-Undang Nomor 22 Tahun 2009 Tentang Lalu Lintas Dan Angkutan Jalan adalah ada seseorang yang melakukannya, yakni pengemudi yang perbuatannya tersebut melawan hukum, “.....dengan sengaja tidak menghentikan kendaraannya, tidak memberi pertolongan, atau tidak melaporkan kecelakaan lalu lintas kepada kepolisian negara republik Indonesia terdekat....." seperti diatur dalam Pasal 312 Undang-Undang Nomor 22 Tahun 2009 Tentang Lalu Lintas Dan Angkutan Jalan merupakan kejahatan yang diancam dengan pidana penjara paling lama 3 (tiga) tahun atau denda. Oleh karena itu, jika pengemudi melanggar ketentuan pasal tersebut, maka pengemudi dapat dipidana, namun berdasarkan teori pertanggungjawaban pidana, unsur-unsur kesalahan pengemudi harus dihubungkan dengan perbuatan pidana yang dilakukan. Sehingga untuk adanya kesalahan yang mengakibatkan dipidananya pengemudi, harus memenuhi beberapa unsur yaitu melakukan perbuatan pidana, mampu bertanggung jawab, dengan kesengajaan atau kealpaan, tidak adanya alasan pemaaf.

\section{Kajian Hukum Positif Terhadap Pelaku Tabrak Lari Yang Mengakibatkan Kematian}

Bagian penting dari pemidanaan adalah penetapan sanksi, sanksi sangat dibutuhkan untuk menegakkan norma. Sanksi dalam hukum pidana merupakan reaksi terhadap pelanggaran hukum yang telah ditentukan undang-undang, dimulai dari penahanan tersangka dan penuntutan terdakwa sampai pada penjatuhan vonis oleh hakim. Penetapan sanksi begitu penting dan strategis,

${ }^{28}$ Dwidja Priyatno, Kebijakan Legislasi ...Op.Cit. hlm40. 
PRESUMPTION of LAW

Fakultas Hukum Universitas Majalengka

Volume 2 Nomor 2 Oktober 2020

sehingga dibutuhkan fondasi yang kuat dalam perumusannya. Fondasi tersebut tidak lain adalah pemahaman terhadap ide-ide dasar mengenai filsafat pemidanaan, teori pemidanaan dan tujuan pemidanaan. ${ }^{29}$

Sekilas mengenai undang-undang lalu lintas dan angkutan jalan yang dulu UU No. 14 tahun 1992, telah mengalami permasalahan dalam aplikasinya. Permasalahan tersebut tidak lain adalah mengenai sanksi, yakni pidana denda yang dikenakan dinilai terlalu tinggi. Sehingga dalam pelaksanaannya terhambat selama satu tahun. dengan adanya persoalan tersebut dapat menjadi wawasan bahwa sanksi denda cukup ditakuti. ${ }^{30}$ Tidak berbeda dengan undangundang lalu lintas sekarang yang juga menerapkan sanksi denda yang berat bagi pelanggarnya, khususnya bagi pelaku tabrak lari.

Hukum pidana adalah hukum sanksi, karena dengan bertumpu pada sanksi tersebut hukum pidana difungsikan untuk menjamin keamanan, ketertiban dan keadilan. ${ }^{31}$ Sebagai salah satu jenis punishment, hukum pidana juga memuat sanksi denda. Sanksi tersebut bukan hanya untuk tujuan-tujuan ekonomis, misal sebagai pemasukan kas negara, melainkan berhubungan dengan tujuan-tujuan pemidanaan (goals of punishment). Tujuan pemidanaan sendiri erat kaitannya dengan falsafah pemidanaan yang dianut suatu bangsa, yang tercermin dalam produk undang-undang yang dihasilkan. ${ }^{32}$

Sanksi dalam hukum nasional muncul dari dua bentuk yang berbeda, yakni sebagai hukuman dan eksekusi sipil. ${ }^{33}$ Hukuman diartikan sebagai pencabutan hak secara paksaan atas suatu nilai. Seperti, hukuman mati yang dipaksakan adalah nyawa, hukuman potong tangan yang dipaksakan adalah anggota badan, hukuman penjara atau kurungan yang dipaksakan adalah kebebasan individu.

Sedangkan eksekusi sipil juga merupakan sejenis paksaan namun lebih menekankan pada pembenahan kesalahan. Tujuan dari eksekusi sipil sendiri adalah mengembalikan kepada situasi semula, yang sesuai dengan ketentuanketentuan hukum. Jika situasi tersebut tidak dapat kembali, maka situasi lain dapat menjadi penggantinya. ${ }^{34}$

Kepastian hukum bagi pelaku tabrak lari banyak merujuk pada Pasal 310 ayat (4) UU No. 22 Tahun 2009 adalah pidana penjara paling lama 6 tahun atau denda paling banyak Rp. 12.000.000, (dua belas juta rupiah) dan Pasal 312 UU No. 22 Tahun 2009 adalah pidana penjara paling lama 3 tahun atau denda paling banyak Rp. 75.000.000, (tujuh puluh lima juta rupiah).

Berkaitan dengan sanksi mengenai tabrak lari, denda yang dikenakan cukup tinggi jika dibandingkan dengan hukuman penjaranya. Terdapat

\footnotetext{
${ }^{29}$ Sholehudin, Sistem Sanksi Dalam Hukum Pidana, ide dasar doubel track system \& implementasinya, cet. Ke-2, PT RajaGrafindo Persada, Jakarta, 2004, hlm. 123

${ }^{30}$ M. Hamdan, Politik Hukum PidanaPT. RajaGrafindo Persada, , Jakarta, 1997, hlm. 131

${ }^{31}$ Ibid

${ }^{32}$ Ibid., hlm. 132-133

${ }^{33}$ Hans Kelsen, Pure teory of law, Terj. Raisul Muttaqien, Teori Hukum Murni (dasardasar ilmu hukum normatif), cet. VI , Nusa Media, , Bandung, 2008, hlm. 124

${ }^{34}$ Ibid
} 
PRESUMPTION of LAW

Fakultas Hukum Universitas Majalengka

Volume 2 Nomor 2 Oktober 2020

beberapa faktor-faktor yang menyebabkan sanksi denda lebih diunggulkan dibanding dengan pidana penjara, pertama, kemampuan finansial masyarakat meningkat. Hal tersebut dibuktikan dengan daya beli masyarakat terhadap kendaraan bermotor. Kedua, berkembangnya delik-delik khusus, seperti "White collar Crime" dan "profesional Crime". Ketiga, semakin tidak disukainya pidana penjara, terutama bagi tindak pidana tertentu seperti ekonomi dan narkotika. Kemudian tidak disukainya pidana penjara ini juga berkaitan dengan efisiensi, jika seseorang yang dipenjara semakin banyak maka pengeluaran negara lebih banyak pula. ${ }^{35}$

Kemudian yang menjadi pertanyaan adalah, bagaimana efektivitas pidana terhadap efek jera atau tujuan pemidaan yang ditimbulkan? Sehingga dengan demikian pidana denda dapat menjadi obat terakhir (ultimum remidium). Terdapat teori yang menyebutkan bahwa efektivitas suatu pidana denda tergantung pada tahap sebagai berikut:

1. Tahap penetapan pidana denda oleh pembuat undang-undang,

2. Tahap pemberian atau penjatuhan pidana denda oleh pengadilan,

3. Tahap pelaksanaan pidana denda oleh aparat yang berwenang. ${ }^{36}$

Namun dari itu semua, penilaian masyarakat cukup berpengaruh. Sehingga efektivitas yang ditimbulkan dapat dilihat dari respons masyarakat. Jika pidana denda kurang memenuhi rasa keadilan maka pidana tidak berhasil guna mencapai tujuan pemidanaan. ${ }^{37}$ Telah disebutkan di atas mengenai faktorfaktor yang menyebabkan sanksi denda lebih diunggulkan dibanding dengan pidana penjara, yang mana faktor-faktor tersebut merupakan kondisi yang dialami masyarakat saat ini.

Pasal 312 Undang-Undang Nomor 22 Tahun 2009 sebagai hukum formal telah mengatur mengenai ketentuan tabrak lari. Namun tidak hanya dari ketentuan tersebut tabrak lari dapat dilihat. Terkait dengan penyelidikan dan penyidikan yang dikembangkan penyidik terhadap setiap peristiwa tabrak lari, selain ketentuan di atas ada kondisi tertentu dimana kondisi tersebut dijadikan sebagai peristiwa tabrak lari. Yakni ketika penyidik datang ke Tempat Kejadian Perkara (TKP) pelaku dan saksi tidak ada. Kemudian dari hasil survei bersama yang dilakukan antara pihak kepolisian dan Jasa Raharja, yang menunjukkan bahwa peristiwa tersebut adalah tabrak lari.

Ketentuan formal di atas yang tertuang dalam Pasal 312 Undang-Undang Nomor 22 Tahun 2009 tidak akan berbicara banyak tanpa adanya proses penyelidikan dan penyidikan. Pasal 312 Undang-Undang Nomor 22 Tahun 2009 hanya memuat ketentuan-ketentuan pada tahap awal saja, yang mana masih memerlukan penyelidikan dan penyidikan guna dibuktikan apakah suatu kecelakaan yang terjadi benar-benar tabrak lari. Sehingga dalam redaksi pasal tersebut menggunakan kata "Setiap orang yang mengemudikan kendaraan

\footnotetext{
${ }^{35}$ M. Hamdan, Politik Hukum Pidana, ....Op.Cit, hlm. 138-139

${ }^{36}$ Ibid, hlm. 135

${ }^{37}$ Ibid. lihat juga Ahmad Miftahul Farid, Tabrak Lari Dalam UU No. 22 tahun 2009 Tentang Lalu Lintas Dan Angkutan Jalan Dalam Perspektif Hukum Pidana Islam. Fakultas Syari'ah Institut Agama Islam Negeri Walisongo Semarang 2012, hlm 58
} 
PRESUMPTION of LAW

Fakultas Hukum Universitas Majalengka

Volume 2 Nomor 2 Oktober 2020

bermotor yang terlibat kecelakaan lalu lintas...", bukan "seseorang yang menabrak..." misalnya, atau sebagainya. ${ }^{38}$

Terlepas dari penyelidikan dan penyidikan, tabrak lari merupakan tindakan amoral, sebagaimana pembahasan sebelumnya. Mengenai hal ini tabrak lari dapat digolongkan sebagai perbuatan kejahatan, sebagaimana Pasal 316 ayat (2) Undang-Undang Nomor 22 Tahun 2009. Tabrak lari pada mulanya adalah tindak pelanggaran yang mengakibatkan ruginya seseorang. ${ }^{39}$ Yakni menabrak karena kelalaian, yang mana perbuatan tersebut tidak diinginkan oleh pelaku atau tidak ada niat untuk melakukan. Sebagaimana seperti ketentuan mengenai kelalaian berkendara di atas. Kemudian terdapat unsur kesengajaan yang merupakan bagian dari unsur tabrak lari, yakni pengemudi tidak menghentikan kendaraannya, tidak menolong, tidak melapor ke polisi terdekat, sebagaimana Pasal 312 UU No. 22 Tahun 2009 di atas.

Adanya kecelakaan merupakan faktor kesalahan pengemudi dengan tidak adanya rasa hati-hati dan lalai mengemudikan kendaraannya. Kesalahan pengemudi kendaraan yang melakukan kealpaan yang mengakibatkan kematian dapat dikatakan bahwa orang itu telah melakukan tindak pidana. Berkaitan dengan masalah ini unsur kealpaan memainkan peranan penting, masalah-masalah kealpaan pada Kitab Undang-Undang Hukum Pidana (KUHP) telah di atur dalam Bab XXI dari buku II yang dimulai dari Pasal 359 sampai dengan Pasal 361 KUHP.

Sanksi pidana bagi pengemudi kendaraan yang karena kealpaannya menyebabkan kematian diatur dalam Pasal 359 KUHP, yakni: "Barangsiapa karena kealpaannya menyebabkan matinya orang lain diancam dengan pidana penjara paling lama lima tahun atau pidana kurungan paling lama satu tahun". ${ }^{40}$

R. Soesilo dalam penjelasannya mengatakan bahwa: "matinya orang disini tidak dimaksud sama sekali oleh terdakwa, akan tetapi kematian tersebut hanya merupakan akibat dari kurang hati-hati atau lalainya terdakwa". ${ }^{41}$ Dengan demikian, bahwa yang menjadi pelaku tindak pidana kecelakaan lalu lintas yang mengakibatkan kematian ialah pengemudi kendaraan karena tindakan yang dilakukan itu bersifat melawan hukum. Sifat melawan hukum tersebut memperlihatkan kesalahan dari pengemudi kendaraan yang berbentuk kealpaan/kelalaian atau dengan kata lain tindakan tersebut tercela dan pelaku menyadari tindakan yang dilakukan tersebut.

Menurut uraian pada Pasal 359 KUHP dapat disimpulkan bahwa apabila kealpaan atau kelalaian pengemudi itu mengakibatkan kematian, ancaman pidananya sebagaimana yang diatur dalam Pasal 359 Kitab Undang-Undang Hukum Pidana

\footnotetext{
${ }^{38}$ Ahmad Miftahul Farid, Tabrak Lari Dalam....Op.Cit. hlm 65

${ }^{39}$ Nina (ed), Menghadapi Kasus Pidana 120 kasus pidana dan risiko hukumnya, Raih Asa Sukses, Jakarta, 2010, hlm. 144

${ }^{40}$ Moeljatno, Kitab Undang-Undang hukum Pidana (KUHP), PT. Bumi Aksara, Jakarta, 1983, hlm. 127

41 R. Soesilo, Kitab Undang-Undang Hukum Pidana (KUHP) Serta KomentarKomentarnya Lengkap Pasal Demi Pasal, Politea Bogor, 1988, hlm, 248.
} 
PRESUMPTION of LAW

Fakultas Hukum Universitas Majalengka

Volume 2 Nomor 2 Oktober 2020

Undang-Undang Nomor 22 Tahun 2009 memuat ketentuan-ketentuan pidana yang tinggi, diantaranya pasal yang berhubungan dengan kecelakaan lalu lintas yang mengakibatkan kematian adalah Pasal 310 ayat (4) dalam hal kecelakaan sebagaimana dimaksud pada ayat (3) yang mengakibatkan orang lain meninggal, dipidana dengan pidana penjara paling lama 6 (enam) tahun dan/atau denda paling banyak Rp. 12.000.000,00 (dua belas juta rupiah).

Berdasarkan penjelasan di atas, hukum positif yang mengatur mengenai tindak pidana tabrak lari dalam UU No. 22 Tahun 2009 diatur secara terpisah, yakni kelalaian yang menyebabkan kecelakaan diatur dalam Pasal 310 ayat (4) dan tindakan melarikan diri dalam Pasal 312. Demikian dapat dikatakan bahwa tabrak lari merupakan perbarengan tindak pidana (Concursus) ${ }^{42}$, yang mana melanggar Pasal 310 mengenai kelalaian dalam berkendara, kemudian melanggar Pasal 312 yakni meninggalkan korbannya atau tidak melapor ke Kepolisian terdekat. Mengenai Concurcus dari tindakan tabrak lari tergolong sebagai Concurcus realis, karena terdapat dua kejadian, yakni menabrak dan meninggalkan korban. Sehingga perbuatan tabrak lari dapat dimasukkan ke dalam satu tindak pidana yang dilakukan dengan menyerupai sengaja. Jika kaitkan dengan teori Negara hukum dalam arti material atau konsep Negara Kesejahteraan berdasarkan Pancasila, yaitu negara tidak dikehendaki hanya membatasi fungsinya untuk pembuatan peraturan-peraturan pidana saja, melainkan lebih jauh lagi yaitu bagaimana melindungi dan menangani permasalahan tabrak lari yang menimbulkan korban meninggal dunia, sehingga tidak menimbulkan letupan atau gejolak sosial di masyarakat.

Jika kita kaitkan dengan teori pertanggungjawaban pidana, unsur-unsur kesalahan pengemudi harus dihubungkan dengan tindak pidana yang dilakukan. Sehingga untuk adanya kesalahan yang mengakibatkan dipidananya pengemudi, harus memenuhi beberapa unsur yaitu melakukan tindak pidana, mampu bertanggung jawab, dengan kesengajaan atau kealpaan, tidak adanya alasan pemaaf.

\section{Faktor Yang Menjadi Kendala Dalam Penegakan Hukum Tabrak Lari Yang Mengakibatkan Kematian.}

Kecelakaan lalu lintas menurut Pasal 1 angka 24 Undang-Undang Nomor 22 Tahun 2009 Tentang Lalu Lintas Dan Angkutan Jalan (UULLAJ) adalah suatu peristiwa di jalan yang tidak diduga dan tidak disengaja melibatkan kendaraan atau pengguna jalan lain yang mengakibatkan korban manusia dan kerugian harta benda. ${ }^{43}$ Terjadinya kecelakaan lalu lintas dipengaruhi oleh beberapa faktor, faktor faktor tersebut seolah bekerja sama sebagai penyebab terjadinya kecelakaan lalu lintas. Semakin menjadi ketika manusianya sendiri terlihat tidak begitu mementingkan keselamatan nyawanya buktinya banyak pengendara motor yang ugal-ugalan tanpa mengenakan helm atau pengendara

\footnotetext{
${ }^{42}$ Barda Nawawi Arief, Sari Kuliah Hukum Pidana II, Badan Penyediaan Bahan Kuliah Fakultas Hukum Universitas Diponegoro, Semarang, 1993, hlm. 49.

${ }^{43}$ Fokusmedia, Empat Undang-Undang Transportasi, Bandung, 2009, hlm, 4-5
} 
PRESUMPTION of LAW

Fakultas Hukum Universitas Majalengka

Volume 2 Nomor 2 Oktober 2020

mobil yang menyepelekan kegunaan dari sabuk pengaman. ${ }^{44}$ Macam-macam faktor penyebab terjadinya kecelakaan lalu lintas yang mengakibatkan kematian antara lain:

1. Faktor manusia.

Faktor manusia merupakan faktor yang paling dominan. Hampir semua kejadian kecelakaan lalu lintas didahului dengan pelanggaran lalu lintas. Pelanggaran dapat terjadi karena sengaja melanggar, ketidaktahuan terhadap arti aturan yang berlaku maupun tidak melihat ketentuan yang diberlakukan atau pula pura-pura tidak tahu. Terjadinya kecelakaan lalu lintas karena kealpaan berasal dari sikap batin dari seorang pengemudi kendaraan, dalam hal ini kecelakaan juga bisa terjadi karena pengemudi kendaraan saat mengendarai kendaraan dalam keadaan mengantuk atau sedang sakit, sedang dibawah pengaruh alkohol sehingga tidak jarang menimbulkan kecelakaan lalu lintas.

2. Faktor kendaraan.

Faktor kendaraan yang kerap kali menghantui kecelakaan lalu lintas adalah fungsi rem dan kondisi ban. Faktor tersebut diantaranya :

a. Fungsi rem. Rem blong ataupun slip ini sudah pasti akan membuat kendaraan lepas kontrol dan sulit untuk diperlambat. Apalagi pada mobil dengan transmisi otomatis yang hanya mengendalikan rem tanpa engine brake. Sebaiknya selalu melakukan pengecekan pada sistem pengereman sebelum bepergian.

b. Kondisi ban. Bahayanya kendaraan susah dikendalikan, bisa saja kendaraan oleng dan terbalik karena beda ketinggian kendaraan akibat ban meletus. Apalagi saat melaju dalam kecepatan yang cukup tinggi tidak jarang menimbulkan kecelakaan lalu lintas.

3. Faktor Jalan.

Faktor jalan juga berperan penting dalam terjadinya suatu kecelakaan. Kondisi jalan yang tidak menentu seperti jalan yang berlubang dapat menyebabkan kecelakaan bagi pengguna jalan terutama kendaraan bermotor. Selain itu kondisi jalan yang berliku seperti kondisi jalan yang ada di daerah pegunungan, jalan yang gelap pada malam hari atau minimnya penerangan jalan dalam hal ini tidak jarang menimbulkan kecelakaan.

4. Faktor lingkungan.

Faktor ini khususnya dalam cuaca gelap pada malam hari dapat mempengaruhi jarak pandang pengemudi kendaraan dalam mengendarai kendaraannya sehingga sering terjadi kecelakaan. Pada musim kemarau yang berdebu juga membahayakan bagi pengguna jalan terutama kendaraan roda dua. Pada keadaan berdebu konsentrasi mata pengendara berkurang sehingga menyebabkan kecelakaan. Jalan

44 Agio V. Sangki, Tanggung Jawab Pidana Pengemudi Kendaraan Yang Mengakibatkan Kematian Dalam Kecelakaan Lalu lintas, https:// media.neliti. com/media/ publications/3140-ID-tanggung-jawab-pidana-pengemudi-kendaraan-yang-mengakibatkankematian-dalam-kece.pdf, diakses pada tanggal 03/12/2019 
PRESUMPTION of LAW

Fakultas Hukum Universitas Majalengka

licin pada waktu hujan baik pengendara roda dua dan empat sering tergelincir atau terjadi selip, hal ini yang menyebabkan pengemudi kendaraan kehilangan kendali sehingga terjadi kecelakaan. Kabut yang tebal dapat mengelabuhi mata seolah-olah tidak ada kendaraan yang melaju karena jarak pandang yang terbatas, hal ini dapat mengakibatkan terjadinya kecelakaan lalu lintas.

Di antara faktor-faktor tersebut faktor manusia merupakan faktor yang paling menentukan. Hal tersebut terjadi karena adanya kecerobohan atau kealpaan pengemudi dalam mengemudikan kendaraannya, kecerobohan pengemudi tersebut tidak jarang menimbulkan kecelakaan lalu lintas yang mengakibatkan kematian. Kesalahan pengemudi dalam berkendaraan, sering dapat disimpulkan tidak mempergunakan peraturan lalu lintas. Misalnya ia tidak memberi tanda akan membelok, atau ia mengendarai mobil tidak di jalur kiri, atau pada suatu persimpangan tidak memberikan prioritas pada kendaraan lain yang datang dari sebelah kiri, atau menjalankan mobil terlalu cepat melampaui batas kecepatan yang ditentukan dalam rambu-rambu lalu lintas. ${ }^{45}$ Adanya kecelakaan merupakan faktor kesalahan pengemudi dengan tidak adanya rasa hati-hati dan lalai mengemudikan kendaraannya. Kesalahan pengemudi kendaraan yang melakukan kealpaan yang mengakibatkan kematian dapat dikatakan bahwa orang itu telah melakukan tindak pidana dan untuk menganalisis faktor-faktor yang menjadi kendala dalam penegakan hukum tabrak lari yang mengakibatkan kematian, terlebih dahulu perlu dikemukakan pendapat dari Soejono Soekanto.

Sehubungan dengan faktor-faktor yang menjadi kendala dalam penegakan hukum tabrak lari yang mengakibatkan kematian, dapat diuraikan sebagai berikut. Pertama, faktor hukumnya sendiri, yang di dalam tulisan ini akan dibatasi pada peraturan perundang-undangan saja. Dalam pelaksanaan/ eksekusi tindak pidana tabrak lari pada dasarnya juga merupakan masalah penegakan hukum. Berdasarkan pisau analisis teori kepastian hukum bahwa hukum dapat mencerminkan nilai-nilai yang menjadi dasar dari hukum itu sendiri. Agar hukum atau peraturan perundang-undangan tersebut dapat berlaku efektif maka harus ada peraturan yang tertulis dalam menanggani pelaku tabrak lari sehingga pelaku menjadi jerah dan lebih berhati-hati dalam berkendara. Sehubungan dengan hal tersebut, peraturan perundang-undangan yang berkaitan dengan tabrak lari dalam Undang-Undang Nomor 22 tahun 2009 tentang lalu lintas dan angkutan jalan (UULLAJ), maka dari faktor hukumnya sendiri telah memiliki kepastian hukum dan sanksi hukum yang jelas, sehingga faktor ini tidak menjadi kendala yang menghambat tujuan dari Undang-Undang Nomor 22 tahun 2009 tentang lalu lintas dan angkutan jalan (UULLAJ) dalam rangka mempercepat pemberantasan tindak pidana tabrak lari yang mengakibatkan kematian di Indonesia.

Kedua, faktor penegak hukum, yakni pihak-pihak yang membentuk maupun menerapkan hukum. Pencapaian supremasi hukum harus diukur dari

45 Wirjono Prodjodikoro, Tindak-Tindak Pidana Tertentu di Indonesia, Eresco Bandung, 1967, hlm. 80 
PRESUMPTION of LAW

Fakultas Hukum Universitas Majalengka

Volume 2 Nomor 2 Oktober 2020

seberapa baik penegakan hukum yang dilakukan di Indonesia, berbicara mengenai penegakan hukum, maka hal paling penting dan mendasar adalah bagimana kemampuan aparat penegak hukum (khususnya dalam bidang tindak pidana lalu lintas), dalam sistem peradilan dapat mengakomodasi dan mengapresiasi tuntutan keadilan baik yang menjadi roh hukum formal maupun tuntutan rasa keadilan oleh masyarakat dalam penindakan tindak pidana tabrak lari yang mengakibatkan kematian merupakan suatu kebutuhan dasar. ${ }^{46}$

Dikemukakan oleh Soejono Soekanto, sebagai salah satu faktor yang menentukan proses penegakan hukum adalah tidak hanya pihak-pihak yang menerapkan hukum tetapi juga pihak-pihak yang membuat hukum. Dalam pembahasan ini dibicarakan mengenai pihak-pihak yang terkait langsung dengan penerapan hukum. Pihak-pihak dalam proses penegakan hukum dimaksud yaitu kepolisian, kejaksaan, kehakiman dan kepengacaraan. ${ }^{47}$

Berdasarkan teori hukum pembangunan yang dijadikan pisau analisis dalam permasalahan ini maka, pola pikir penegakan hukum tidak harus berdasarkan terompet undang-undang saja namun harus bisa melakukan pembaharuan hukum/kriminalisasi dengan cara menemukan gagasan baru, regulasi dan revitalisasi terhadap peraturan yang sudah ada, yang bersumber pada nilai-nilai yang hidup dalam masyarakat.

Ketiga, faktor masyarakat, yakni lingkungan di mana hukum tersebut berlaku atau diterapkan. Bagian terpenting dari masyarakat dalam yang menentukan penegakan hukum adalah kesadaran hukum masyarakat. Peraturan hukum yang berlaku atau diterapkan mempunyai pengaruh yang kuat terhadap pelaksanaan penegakan hukum. Sebab penegakan hukum berasal dari masyarakat dan bertujuan untuk mencapai kedamaian dan keadilan dalam masyarakat.

Kaitannya dengan faktor yang menjadi kendala dalam penegakan hukum tabrak lari yang mengakibatkan kematian adalah kurangnya kesadaran dari masyarakat untuk melaporkan atau memberitahukan telah terjadinya tindak pidana tabrak lari yang mengakibatkan kematian. Kepedulian atau kesadaran masyarakat untuk memberikan informasi secara dini kepada penegak hukum terhadap orang yang dicurigai melakukan tindak pidana tabrak lari yang mengakibatkan kematian masih kurang, justru ada kecenderungan untuk turut menutup-nutupi.

Sehubungan dengan faktor masyarakat yang ikut mempengaruhi penegakan hukum ini, apabila dikaitkan dengan pendapat Friedman tentang unsur-unsur dalam sistem hukum yang salah satu unsurnya adalah "budaya hukum" yaitu sikap-sikap dan nilai yang berhubungan dengan hukum, yang datangnya dari rakyat atau pemakai jasa hukum, ${ }^{48}$ maka dapat di kemukakan bahwa budaya hukum masyarakat yang dicerminkan antara lain dengan sikap masyarakat yang enggan memberikan informasi tentang adanya pelaku tindak

\footnotetext{
${ }^{46}$ Sidik Sunaryo, Kapita Selekta Peradilan Pidana, Universitas Muhammadiyah Malang, 2005, hlm. 337

47 Soerjono Soekanto, Op.Cit, hlm. 13

48 Abdul Manan, Aspek-aspek Pengubah Hukum, Prenada Media Group, Jakarta, 2005, hlm. 9
} 
PRESUMPTION of LAW

Fakultas Hukum Universitas Majalengka

Volume 2 Nomor 2 Oktober 2020

tabrak lari yang mengakibatkan kematian di lingkungannya. Ini menunjukan adanya budaya hukum masyarakat yang belum mendukung penegakan tindak tabrak lari yang mengakibatkan kematian. Sehingga dapat dikatakan bahwa faktor masyarakat khususnya budaya hukum masyarakat merupakan faktor penghambat dalam penanggulangan tabrak lari yang mengakibatkan kematian.

Berdasarkan uraian tentang faktor-faktor yang menjadi kendala tabrak lari yang mengakibatkan kematian, maka dapat dikemukakan bahwa faktorfaktor tersebut meliputi tidak ada hambatan dari faktor hukumnya, karena penindakan tindak pidana tabrak lari yang mengakibatkan kematian memiliki dasar hukum yang kuat sehingga faktor ini tidak menjadi kendala yang menghambat tujuan dari pada Undang-Undang Nomor 22 Tahun 2009 tentang Lalu Lintas dan Angkutan Jalan (UULLAJ) dalam rangka mempercepat Penindakan Tindak Pidana tabrak lari di Indonesia. Namun penyelesaian perkara kecelakaan lalu lintas oleh pelaku tindak pidana tabrak lari, pihak kepolisian mengalami kendala pada proses penyelidikan dan penyidikan hingga ke penyelesaian proses perkara lebih lanjut, baik itu kendala Eksternal maupun kendala Internal.

Kendala eksternal yang di dapat karena faktor luas wilayah yang berpengaruh terhadap penyidikan dan penyelidikan kasus kecelakaan lalu lintas juga memberikan suatu hambatan yang tidak sedikit, barang bukti (kendaraan bermotor) yang dikemudikan pelaku tabrak lari tidak memiliki Nomor Polisi atau yang biasa ditemukan barang bukti (kendaraan bermotor) bukan nama pemilik pertama, melainkan pelaku merupakan pemilik ke sekian dari barang bukti kendaraan bermotor akibatnya sulit untuk melacak pelaku tabrak lari yang melarikan diri. Selain itu waktu kejadian dalam kasus kecelakaan tabrak lari, waktu dan tempat kejadian juga mempengaruhi yaitu antara yang terjadi di siang hari dengan yang terjadi di malam hari dan kasus terjadi di daerah yang jauh daripemukiman masyarakat ${ }^{49}$. Kendala lain ialah kendala dalam melakukan pemanggilan saksi.

Selanjutnya kendala Internal yang dihadapai oleh pihak Kepolisian ialah meliputi faktor sarana dan prasarana yang dimiliki oleh Unit Kecelakaan Lalu Lintas Kepolisian Resort Majalengka kurang memadai untuk mendukung kinerja Polri agar berjalan maksimal, selain itu luas wilayah di Kabupaten Majalengka yang besar tidak didukung dengan jumlah personil anggota Kepolisian Resort Majalengka yang memadai, biaya yang mahal dalam proses penyidikan dan penyelidikan serta terbatasnya anggaran juga menjadi faktor kendala utama ditingkat internal Polri.

Disamping kendala yang di sebutkan di atas, ada kendala-kendala lain yang di hadapi Polisi Resort Majalengka dalam memberikan perlindungan hukum bagi pelaku tindak pidana tabrak lari Pasal 310 ayat (4) UndangUndang Nomor 22 Tahun 2009 tentang Lalu Lintas dan Angkutan Jalan terdapat dalam proses penyidikan yaitu:

${ }^{49}$ Franky Dontin Tobing, Penyelesaian Perkara Dalam Pelanggaran Pasal 312 Undang-Undang Nomor 22 Tahun 2009 Tentang Lalu Lintas Dan Angkutan Jalan Di Wilayah Hukum Kepolisian Resor Kota Pekanbaru, JOM Fakultas Hukum Volume II Nomor II Oktober 2015, hlm 12 
PRESUMPTION of LAW

Fakultas Hukum Universitas Majalengka

Volume 2 Nomor 2 Oktober 2020

1. Keluarga korban tidak mengijinkan di lakukan otopsi pada korban, apabila pada korban kecelakaan Lalu Lintas tidak dilakukan pemeriksaan otopsi maka akan mempersulit penyidik untuk mengembangkan dan memberikan keterangan di berkas perkara. Jika keluarga korban tidak mau dilakukan otopsi biasanya keluarga korban melakukan penyelesaian perkara pidana ini secara kekeluargaan.

2. Pelaku sulit untuk dimintai keterangan, hal ini terjadi karena kondisi psikologis pelaku yang sedikit terguncang akibat ketakutan yang dialami pelaku dan tekanan baik dari diri sendiri maupun dari pihak yang lain yang akan mengakibatkan keterangan yang di berikan pelaku kepada polisi penyidik terbatas dan cenderung kurang akurat. Dalam hal ini polisi harus mencari solusi yang baik agar membuat pelaku menjadi tenang, nyaman tanpa tekanan dari pihak manapun. Agar pelaku mudah untuk dimintai keterangan.

3. Meminta kepada polisi untuk tidak melanjutkan perkara ke pengadilan, polisi akan sulit memberikan perlindungan kepada pelaku karena kelanjutan perkara tersebut belum tentu mencapai kesepakat kedua belah pihak untuk berdamai, dikawatirkan masih ada pihakpihak yang tidak terima.

4. Sulit mencari saksi dalam kejadian, dalam kejadian kecelakan sangat sulit untuk mencari saksi yang mau mengetahui kejadian yang sebenarnya, karena menurut saksi hal tersebut akan menyita waktu mereka dan kebanyakan para saksi hanya melihat sekilas, apa lagi kejadian tersebut terjadi ditempat yang sepi hal tersebut membuat polisi sulit menentukan perkara kejadian karena saksi tidak jelas melihat kejadian bahkan tidak ada saksi sama sekali

5. Adanya kesepakatan bersama antara para pihak, biasanya para pihak menyelesaiakan perkara dengan melakukan kesepakatan sendiri, hal tersebut membuat polisi sulit untuk melakukan penyidikan sehingga kasus terhenti. ${ }^{50}$

Kelima faktor tersebut saling berkaitan dengan eratnya, oleh karena merupakan esensi dari penegakan hukum, juga merupakan tolak ukur dari pada efektivitas penegakan hukum dalam menindak tindak pidana tabrak lari yang mengakibatkan kematian.

\section{E. Kesimpulan}

Berdasarkan pembahasan yang diuraikan pada bab sebelumnya, dapat ditarik kesimpulan sebagai berikut :

1. Hukum positif yang mengatur tindak pidana tabrak lari, dalam UU No. 22 Tahun 2009 diatur secara terpisah, yakni kelalaian yang menyebabkan kecelakaan diatur dalam Pasal 310 ayat (4) dan tindakan melarikan diri dalam Pasal 312. Dengan demikian dapat dikatakan bahwa tabrak lari

${ }^{50}$ Hasil wawancara dengan KANIT LAKALANTAS Polres Majalengka, dikantor laka lantas malang kota pada tanggal 28 November 2014 pukul 10.30 WIB 
merupakan perbarengan tindak pidana (Concursus). Mengenai Concurcus dari tindakan tabrak lari tergolong sebagai Concurcus realis, karena terdapat dua kejadian, yakni menabrak dan meninggalkan korban.

2. Faktor yang menjadi kendala dalam penegakan hukum tabrak lari yang mengakibatkan kematian adalah kurangnya kesadaran dari masyarakat untuk melaporkan atau memberitahukan telah terjadinya tindak pidana tabrak lari yang mengakibatkan kematian. Adanya budaya hukum masyarakat yang belum mendukung penegakan tindak tabrak lari yang mengakibatkan kematian.

\section{F. Saran}

Mengingat bahaya tindak pidana tabrak lari yang mengakibatkan kematian bagi kelangsungan hidup berbangsa dan bernegara, maka perlu disarankan sebagai berikut:

1. Bagi Pemeritah dan badan legislatif harus menambah redaksi peraturan mengenai tindak pidana tabrak lari yang mengakibatkan kematian. Hal ini dikarenakan Undang-Undang Nomor 22 Tahun 2009 tidak mengatur secara spesifik perbuatan tabrak lari yang mengakibatkan kematian.

2. Bagi Masyarakat hendaknya mematuhi peraturan yang sudah dibuat dan disosialisasikan oleh aparat kepolisian sehingga dalam berkendara di jalan raya harus lebih berhati-hati dan tertib didalam peraturan lalu lintas seperti dengan membawa surat kelengkapan dalam berkendara. 
PRESUMPTION of LAW

Fakultas Hukum Universitas Majalengka

Volume 2 Nomor 2 Oktober 2020

\section{DAFTAR PUSTAKA}

\section{A. Buku-buku}

Abdul Manan, Aspek-aspek Pengubah Hukum, Prenada Media Group, Jakarta, 2005

Ahmad Miftahul Farid, Tabrak Lari Dalam UU No. 22 tahun 2009 Tentang Lalu Lintas Dan Angkutan Jalan Dalam Perspektif Hukum Pidana Islam. Fakultas Syari'ah Institut Agama Islam Negeri Walisongo Semarang 2012.

Ahmad Miftahul Farid, Tabrak Lari Dalam UU No. 22 Tahun 2009 tentang Lalu Lintas Dan Angkutan Jalan Dalam Perspektif Hukum Pidana Islam. Fakultas Syari'ah Institut Agama Islam Negeri Walisongo Semarang 2012.

Angelika Rili Anita, Upaya Kepolisian Dalam Memberikan Perlindungan Bagi Korban Tabrak Lari,Jurnal, Fakultas Hukum Universitas Atma Jaya Yogyakarta 2015.

Ateng Sudibyo, Kebijakan Kriminal Tindak Pidana Poligami Dalam Hukum Perkawinan Di Indonesia, CV. Andy Oetama, Medan, 2018

B. Hestu Cipto Handoyo, Hukum Tata Negara, Kewarganegaraan \& Hak Asasi Manusia, Memahami Proses Konsolidasi Sistem Demokrasi di Indonesia, Cetakan Pertama, Universitas Atma Jaya, Yogyakarta, 2003

Bambang Poernomo, Asas-asas Hukum Pidana, Jakarta: Cetakan ketujuh, Ghalia Indonesia, 1994.

Jakarta,2002.

Barda Nawawi Arief, Sari Kuliah Hukum Pidana II, Badan Penyediaan Bahan Kuliah Fakultas Hukum Universitas Diponegoro, Semarang,1993.

Bisri Ilbam, Sistem Hukum Indonesia, Grafindo Perseda, Jakarta, 1998.

Budi Rizki Husin, studi lembaga penegak hukum, Universitas Lampung, Bandar Lampung ,2014

Dwidja Priyatno, Kebijakan Legislasi Tentang Sistem Pertanggungjawaban Pidana Korporasi di Indonesia, CV.Utomo, Bandung, 2009

E. Utrecht, Hukum Pidana I, Pustaka Tinta Mas, Surabaya,1999.

E. Utrecht, Pengantar Hukum Administrasi Negara Indonesia, Ichtiar, Jakarta, 1962.

Erdianto, Pokok-Pokok Hukum Pidana, Alaf Riau, Pekanbaru, 2010

Esmi Warassih, Pranata Hukum Sebuah Telaah Sosiologis, PT. AI Suryandaru Utama, Semarang, 2005.

Fokusmedia, Empat Undang-Undang Transportasi, Bandung, 2009.

Hans Kelsen, Pure teory of law, Terj. Raisul Muttaqien, Teori Hukum Murni (dasar-dasar ilmu hukum normatif), cet. VI , Nusa Media, , Bandung, 2008.

Kunarto, Perilaku Organisasi Polri, Cipta Manunggal, Jakarta, 2001.

L.J. van Apeldoorn, Pengantar Ilmu Hukum, terjemahan Oetaris Sadino dari Inleiding tot de Studie van het Nederlanse Recht. Pradnya Paramita, cetakan ke-29, Jakarta, 2001. 
PRESUMPTION of LAW

Fakultas Hukum Universitas Majalengka

Volume 2 Nomor 2 Oktober 2020

M. Hamdan, Politik Hukum Pidana, PT. RajaGrafindo Persada, Jakarta, 1997.

M. Karjadi, Dana Pertanggungjawaban Wajib Kecelakaan Penumpang Dan Kecelakaan Lalu Lintas (Kewajiban Dan Wewenang Polisionil). Politeia, Bogor, 1975.

Martiman Prodjohamidjojo, Memahami dasar-dasar hukum Pidana Indoesia, PT. Pradnya Paramita, Jakarta, 1997.

Marye Agung kusmagi, Selamat Berkendara Di Jalan Raya, Raih Asa Sukses, Jakarta,2010.

Miriam Budiardjo, Dasar-dasar Ilmu Politik, Gramedia Pustaka Utama, Jakarta, 1998.

Mochtar Kusumaatmadja, Hukum, masyarakat dan pembinaan hukum Nasional, Binacipta, Jakarta, 1995

Moeljatno, Kitab Undang-Undang hukum Pidana (KUHP), PT. Bumi Aksara, Jakarta, 1983.

Moeljatno, Kitab Undang-undang Hukum Pidana, Bumi Aksara., Jakarta, 2009

Moh. Kusnardi dan Bintan Saragih, Ilmu Negara, Edisi Revisi, Cetakan Keempat, Gaya Media, Jakarta, 2000

Muhammad Tahir Azhary, Negara Hukum: Suatu Studi tentang Prinsipprinsipnya Dilihat dari Segi Hukum Islam, Implementasinya pada Periode Negara Madinah dan Masa Kini, Bulan Bintang, Jakarta, 1992

Muladi dan Dwidja Priyatno, Pertanggungjawaban Korporasi Dalam Hukum Pidana, STHB, Bandung, 1991 , Pertanggungjawaban Pidana Korporasi, Kencana Prenadamedia Group, Jakarta, 2013

N.E. Algra et al, Mula Hukum, terjemahan J.C.T. Simorangkir dari Rechtsaanvang. Binacipta, Jakarta,1983.

Nina (ed), Menghadapi Kasus Pidana 120 kasus pidana dan risiko hukumnya, Raih Asa Sukses, Jakarta, 2010.

Philipus M. Hadjon, Perlindungan Hukum bagi Rakyat Indonesia, Bina Ilmu, Surabaya, 1987

R. Otje Salman S. dan Anton F. Susanto, Teori Hukum, (Mengingat, Mengumpulkan dan Membuka Kembali), Refika Aditama, Cetakan Kelima, Bandung, 2009.

R. Soesilo, Kitab Undang-Undang Hukum Pidana (KUHP) Serta KomentarKomentarnya Lengkap Pasal Demi Pasal, Politea Bogor, 1988.

Ramdlon Naning, Menggairahkan Kesadaran Hukum Masyarakat dan Disiplin Penegak Hukum dalan Lalu Lintas, Surabaya, Bina Ilmu, 1983

Roeslan Saleh, Perbuatan Pidana dan Pertanggungjawaban Pidana; Dua Pengertian Dasar dalam Hukum Pidana, Aksara Baru, Jakarta,1983

Romli Atmasasmita, "Asas-asas Perbandingan Hukum Pidana”, Yayasan LBH, Jakarta, 1989.

Aneska, Jakarta, 2009.

Roscoe Pound, An Introduction to the Philosophy of Law, Yale University Press, United States, 1922 
PRESUMPTION of LAW

Fakultas Hukum Universitas Majalengka

Volume 2 Nomor 2 Oktober 2020

Schaffmeister.D., N. Keijzer, E.PH.Sutorius, Hukum Pidana, Editor Penerjemah J.E. Sahetapy, Yogyakarta, Liberty,1995.

Sekretariat Jendral dan Kepaniteraan Mahkamah Konstitusi RI, Undangundang Dasar 1945, Jakarta, cet. ke-11, 2010.

Setiyono, Menghadapi Kasus Pidana,120 kasus pidana dan risiko hukumnya. Raih Asa Sukses, Jakarta, 2010.

Sholehudin, Sistem Sanksi Dalam Hukum Pidana, ide dasar doubel track system \& implementasinya, cet. Ke-2, PT RajaGrafindo Persada, Jakarta, 2004.

Sidik Sunaryo, Kapita Selekta Peradilan Pidana, Universitas Muhammadiyah Malang, 2005, Soejono Soekanto, Faktor-Faktor Yang Mempengaruhi Penegakan Hukum, Rajawali Pers,Jakarta,1983.

Soemitro Ronny Hanitijo, Metode Penelitian Hukum dan Yurimetri, Ghalia Indonesia, Jakarta, 1988.

Soerjono Soekanto dan Sri Mamudji, Penelitian Hukum Normatif, Suatu Tinjauan Singkat, Rajawali, Jakarta,1985

Sudarto, Hukum Pidana 1, Bahan Penyediaan Kuliah FH UNDIP, Semarang, 1988

---------, Hukum Pidana I, Yayasan Sudarto, Semarang,1990

Sudikno Mertokusumo, Bab-bab tentang Penemuan Hukum, Citra Aditya Bakti, Bandung, 1993

Sugiyono, Metode Penelitian Kuantitatif, Kualitatif dan $R \& D$, Cetakan Kesembilan, Alfabeta,Bandung, 2010.

Sutrisna, I Gusti Bagus, "Peranan Keterangan Ahli dalam Perkara Pidana ( Tijauan terhadap pasal 44 KUHP)," dalam Andi Hamzah (ed.), Bunga Rampai Hukum Pidana dan Acara Pidana Ghalia Indonesia, Jakarta, 1986, hlm. 78

Syamsuharya Berhan. Penerapan Prinsip Hukum Pelestarian Fungsi Lingkungan Hidup dalam Aktivitas Industri nasional. Sebuah Upaya Penyelamatan Lingkungan Hidup dan Kehidupan Antar Generasi, P.T Alumni,Bandung, 2008

Tatang Sugandi, et al. Vademikum Polisi Lalu Lintas, Markas Besar Polisi Lalu Lintas, Jakarta,1999.

Toto Suprapto, Keprihatinan Etika Berlalu Lintas, dalam Suara Merdeka, Semarang, 19 September 2011

Uma Sekaran, Research Methods for Business, A Skill-Building Approach, Illionis: Southern Illionis University at Carbondale (SIUC), 1984,

Usep Ranawijaya, Hukum Tata Negara, Dasar-dasarnya, Ghalia, Jakarta,1983

W.J.S. Purwodarminto, Kamus Umum Bahasa Indonesia, Balai Pustaka, Jakarta, 1986.

Warsito Hadi Utomo, Hukum Kepolisian di Indonesia,Prestasi Pustaka, Jakarta, 2005.

Wirjono Prodjodikoro, Asas-asas Hukum Pidana, Refika Aditama, Bandung, 2003. 1967. 
PRESUMPTION of LAW

Fakultas Hukum Universitas Majalengka

Volume 2 Nomor 2 Oktober 2020

\section{B. Peraturan Perundang-undangan}

Undang-Undang Dasar Negara Republik Indonesia Tahun 1945.

Undang-Undang Nomor 22 Tahun 2009 Tentang Lalu Lintas Dan Angkutan Jalan

Undang-undang Republik Indonesia Nomor 12 Tahun 2011 tentang Pembentukan Peraturan Perundang-undangan

Kitab Undang-undang Hukum Pidana.

\section{Sumber Lain}

\section{Makalah/Surat Kabar}

Barda Nawawi Arief, Masalah Pemidanaan Sehubungan dengan Perkembangan Delik-delik Khusus dalam Masyarakat Modem, Kertas Kerja pada Seminar Perkembangan Delik-delik Khusus dalam Masyarakat yang Mengalami Modernisasi BPHN-FH UNAIR Surabaya, tanggal 25-27 Februari 1980, Binacipta, Bandung, 1982.

Moeljatno, Perbuatan Pidana Dan Pertanggungjawaban Dalam Hukum Pidana, Jakarta, Bina Aksara, 1983 Pidato Diucapkan Pada Upacara Dies Natalis ke-6 Universitas Gadjah Mada, di Sitihinggil Yogyakarta, pada Tanggal 19 Desember 1955

Sudarto, Hukum Pidana 1 A - 1B. Fakultas Hukum Universitas Jenderal Soedirman, Purwokerto, 1990/1991.

Toto Suprapto, Keprihatinan Etika Berlalu Lintas, dalam Suara Merdeka, Semarang, 19 September 2011

Franky Dontin Tobing, Penyelesaian Perkara Dalam Pelanggaran Pasal 312 Undang-Undang Nomor 22 Tahun 2009 Tentang Lalu Lintas Dan Angkutan Jalan Di Wilayah Hukum Kepolisian Resor Kota Pekanbaru, JOM Fakultas Hukum Volume II Nomor II Oktober 2015.

\section{Skripsi/Tesis/ Disertasi}

Arzen Aprillia, Peran Kepolisian Dalam Penanggulangan Pelanggaran Lalu Lintas Oleh Anak Sebagai Pengendara Sepeda Motor (Studi di Satlantas Polres Kabupaten Lima Puluh Kota) Fakultas Hukum Universitas Andalas Padang 2019

Baso Hamka, Tinjauan Kriminologis Tindak Pidana Kecelakaan Lalu Lintas Pada Polres Maros, (studi kasus tahun 2014 - 2015), Fakultas hukum Universitas hasanuddin Makassar 2017

Rukmana Amanwinata, "Pengaturan dan Batas Implementasi Kemerdekaan Berserikat dan Berkumpul dalam Pasal 28 UUD 1945”, Disertasi, Program Pascasarjana Universitas Padjadjaran, Bandung, 1996.

Tengku Erwinsyahbana, "Perspektif Hukum Perkawinan Antar Agama yang Berkeadilan Dikaitkan dengan Politik Hukum Perkawinan Indonesia dalam Rangka Pembangunan Hukum Keluarga Nasional”, Disertasi, Fakultas Hukum Program Doktor Ilmu Hukum Pascasarjana Universitas Padjadjaran, Bandung, 2012.

\section{Internet}

Agio V. Sangki, Tanggung Jawab Pidana Pengemudi Kendaraan Yang Mengakibatkan Kematian Dalam Kecelakaan Lalu lintas, https:// 
media.neliti. com/media/ publications/3140-ID-tanggung-jawabpidana-pengemudi-kenda-raan-yang-mengakibatkan-kematian-dalamkece.pdf diakses pada tanggal 03/12/2019

Dedek buana, Tugas Pokok, Fungsi dan Peranan Polisi Lalu-lintas [POLANTAS], http://artikelddk.com/tugas-fungsi-dan-peranan-polisilalu-lintas-polantas/, di akses tanggal 1 Desember 2019

Marsel Selamat,Pembangunan Hukum Berbasis Masyarakat Suatu Telaah Dalam Perspektif Cita Hukum, http://www.scribd. com/doc / I953 931O/ Pembangunan-Hukum-Berbasis-Masyarakat-Suatu-TelaahDalam-Perspektif-Cita-Hukum, di akses pada tanggal , 25 November 2019

Yance Arizona, “Apa Itu Kepastian Hukum?”, http:// yancearizona. Word press. com, diakses tanggal 12 November 2019 